\section{SPLINT FOR BOW-LEGS IN CHILDREN.} To the Editor of THE LANCET.

Sin,-During twenty years' practice I have often found myself in a great difficulty with regard to treating the very common affection of bow-legs in young children, and especially in cases not depending on disease. I admit in starting that I have succeeded in straightening some with the legiron, but it is a cruel instrument to place on the leg of a child beginning to walk, owing to its weight being fully half a pound, together with the attached boot, which must of necessity be worn with it. Another drawback to it for general use is its great expense, which places it completely out of the reach of the majority. In fact, the leg-iron is only suitable for the different forms of talipes, but for want of a better appliance I have used it myself in cases of bowlegs, there being nothing beside it so far to be had except the common straight padded wooden splint, which is comparatively useless owing to the impossibility of keeping it in position unless the child be kept constantly lying, a resort to which would be out of the question in a healthy child of a year old, the proper time to interfere; besides, the common straight splint requires to be bandaged on, and if not done evenly must worry the little patient.

There is another great objection to those two appliances, their unsightly appearance, in itself enough to deter almost anyone from adopting them, even if the parents could be persuaded of their complete success, as they attract attention so much to the deformity. Very often, if you ask the parents, as their children are growing up with bowlegs, why they had not attended to them in infancy, the general answer is, "The doctor told us they would become straight as the child grew up." And why do the doctors say so? Simply because there is not an effectual light and cheap appliance to be had for the purpose.

The splint I wish briefly to bring before your notice, and of which $I$ subjoin a woodcut, professes to remove those

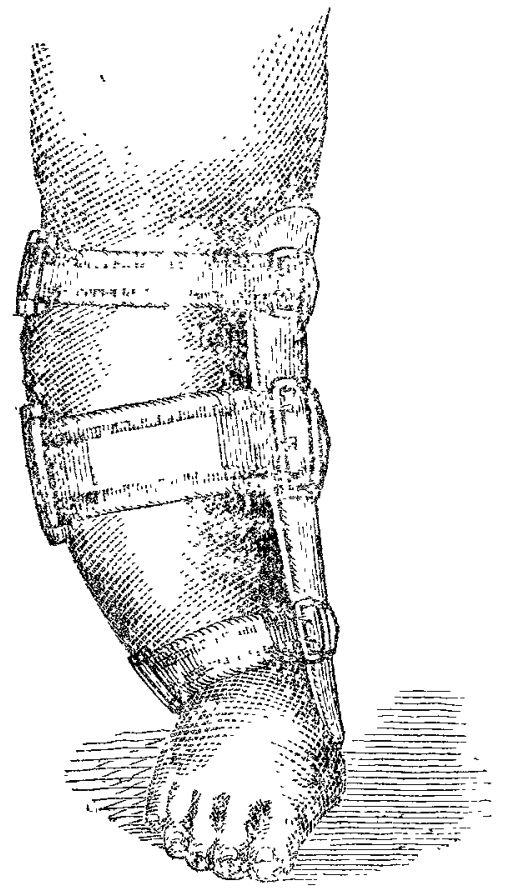

wants and disadvantages, as it combines lightness, cheapness, durability, easy application, together with sightliness and comfort to the child, the whole apparatus weighing little over two ounces, neither wood nor iron entering into its composition. It is adapted from the patent plastic felt, and for which there are already two patents, but zeither of which has before been used for this purpose. When this material was first introduced to my notice I at once was struck with the idea of trying it for bow-legs. At first I applied it on the outside of the leg, making the bow part my fulcrum; but, from experience, found that did not suit then $I$ adapted it to the inside, making the fulcrum at the garter and ankle-joint, with the desired result.

In order to secure a perfect fit it is necessary to have it moulded to the leg in its soft condition, thus adapting itself closely to the parts, on which it is intended to press evenly, leaving the curve free. The top and bottom straps are merely for the purpose of keeping the splint in position, and the centre broad one to act on the curve with pressure as necessary. It covers the ankle-joint, to which it is moulded, slightly padded as well as at the top, and extends far enough below it to prevent the foot turning inwards, as it is generally inclined to do in those cases either with or without weak ankles, but not in the least impeding the action of the joint. As it is shaped to the calf, and extends more than half way around it, there is not the least fear of its changing position. This I have proved in several cases, and which $I$ think one of its greatest adrantages.

I have applied this splint in cases of rickety children, and with even more speedy success, as the bones adapt them. selves with less pressure. It may be applied when the child is six months old, and, if the legs-are not sufficiently straight, at twelve months. Shoes or jicht boots should be worn with it; but on no account to use strong leather boots with the idea of supporting the ankles.

Without encroaching too much on rour space, I hope I have said sufficient to explain what I trust may be found a useful appliance in this very common deformity among children, and which I am confident requires only to be tried to prove its utility. - I am, Sir, \&c.,

Oakley-street, Chelsea.

H. FISEER, M.D.

\section{"WOOLSORTERS" DISEASE." \\ To the Editor of THE LANCET.}

SIR,-Dr. Tibbits practically asks me to repent in fuls detail, with drawings and specimens, my third and fourth Brown Lectures. In these lectures I dealt in detail with the points which he has raised, and subsequently demonstrated a large number of specimens, photographs, \&c., on which the conclusions were based, and by which they are minly sustained. I regret that in the nature of things it is im. possible for me to repeat this in your columns. If, lowever, Dr. Tibbits will read the admirable abstracts furrished by your reporters, he will, I think, find many of his queries answered. For the rest, I trust that in my report on the pathology of the disease to be made to the medical oficer of the Local Government Board he will find sufficient detail of evidence to satisfy him, and I shall always be happy to assist the Bradford Commission in any way in my power. Yours faithifully

Feb. 7th, 1881

W. S. GREENFIELD,

\section{MEDICAL NOTES IN PARLIANENT.}

Noxious Gases.

IN the House of Lords on" Monday a Bill relating to Alkals Works was read a first time. The Marquis of Huntly sail he proposed to take the second reading on the 15 th inst.

Rivers Conservancy and Floods Prevention Bill.

On the motion of Earl Spencer the following Peers were nominated the Select Committee on this Bill :- Earl Spencer, the Duke of Somerset, the Duke of Beaford, the Duke of Marlborough, the Marquis of Huntly, the Earl of Derby, the Earl of Sandwich, the Earl of Jersey, the Earl of Camperdown, Viscount Bury, Lord Monson, Lord Penrhyn, and Lord Norton.

In the House of Commons on Thursday, February 3rd, the Burial and Registration Acts (Doubts Removal) Bill (Lords) was read a third time, and passed. The order for the second reading of the Medical Appointments Qualifications Bill was deferred for a week. The atmosphere in the House throughout this sitting was oppressively warm ; and Sir G. Campbell gave notice of a question to the First Commis. sioner of Works on the subject.

On Friday a petition for inquiry into the East India Army Medical Department was presented from Arthur Barclay.

On Monday a petition was presented from Jobn Piethall for redress in connexion with the Indian medical serrice. Re. turns were presented of correspondence and evidence relating to inquiries at Dromore and Belfast worlihouses. In reply to Sir George Balfour and Mr. Pugh, the Narquis of Hartington said he hoped shortly to present to Parliament papers connected with the recent changes in the Indian Medical Department.

On Tuesday a return was moved for by Sir George Balfour on behalf of Mr. John Talbot, and ordered, of the 